
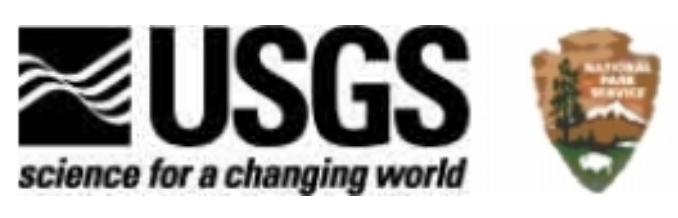

\title{
Coastal Vulnerability Assessment of War in the Pacific National Historical Park (WAPA) to Sea-Level Rise
}

By Elizabeth A. Pendleton, E. Robert Thieler, and S. Jeffress Williams

Any use of trade, firm, or product names is for descriptive purposes only and does not imply endorsement by the U.S. Government

\section{Open-File Report 2005-1056}

U.S. Department of the Interior U.S. Geological Survey 


\title{
U.S. Department of the Interior \\ Gale A. Norton, Secretary
}

\section{U.S. Geological Survey \\ P. Patrick Leahy, Acting Director}

\author{
U.S. Geological Survey, Reston, Virginia 2005-1056 \\ For Additional Information: \\ See the National Park Unit Coastal Vulnerability study at http://woodshole.er.usgs.gov/project-pages/nps-cvi/, \\ the National Coastal Vulnerability study at http://woodshole.er.usgs.gov/project-pages/cvi/, \\ or view the USGS online fact sheet for this project in PDF format at http://pubs.usgs.gov/fs/fs095-02/. \\ To visit the Pacific National Historical Park Web site go to http://www.nps.gov/wapa/index.htm. \\ Contact: \\ Elizabeth A. Pendleton, E. Robert Thieler, S. Jeffress Williams \\ U.S. Geological Survey \\ 384 Woods Hole Road \\ Woods Hole, MA 02543 \\ ependleton@usgs.gov,rthieler@usgs.gov, jwilliams@usgs.gov \\ Telephone: $508-457-2259$ or $508-548-8700$ \\ Rebecca Beavers \\ National Park Service \\ Natural Resource Program Center \\ Geologic Resources Division \\ P.0. Box 25287 \\ Denver, CO 80225-0287 \\ Rebecca_Beavers@nps.gov \\ Telephone: 303-987-6945 \\ For product and ordering information: \\ World Wide Web: http://www.usgs.gov/pubprod \\ Telephone: 1-888-ASK-USGS
}

For more information on the USGS - the Federal source for science about the Earth, its natural and living resources, natural hazards, and the environment:

World Wide Web: http://www.usgs.gov

Telephone: 1-888-ASK-USGS

Although this report is in the public domain, permission must be secured from the individual copyright owners to reproduce any copyrighted material contained within this report. 


\section{Contents}

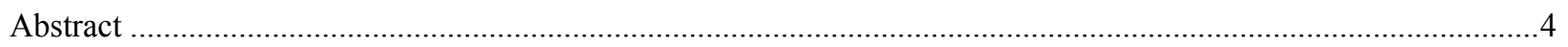

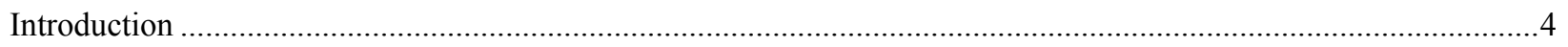

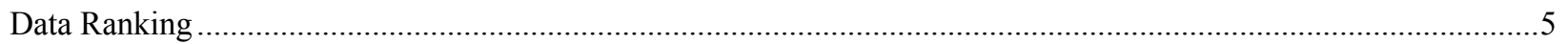

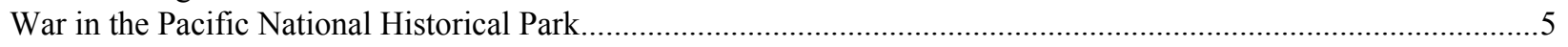

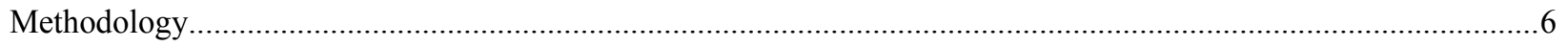

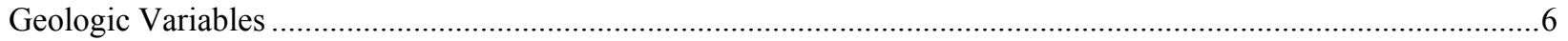

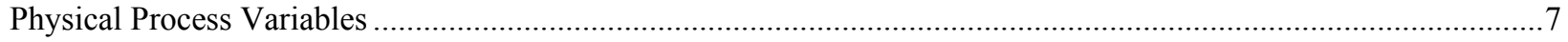

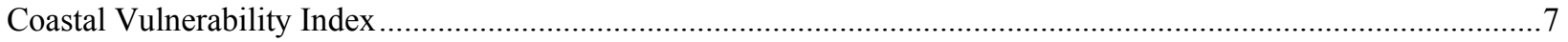

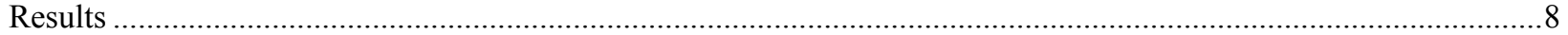

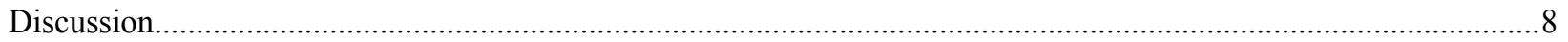

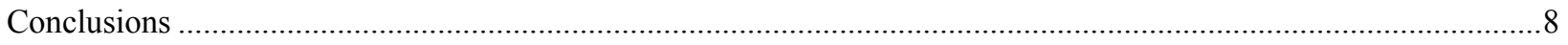

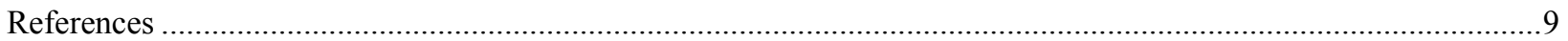

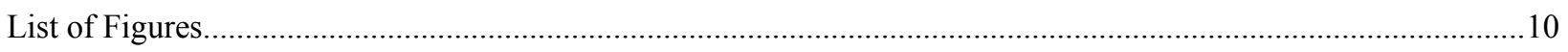

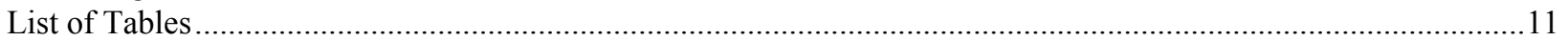




\title{
Coastal Vulnerability Assessment of War in the Pacific National Historical Park to Sea-Level Rise
}

\author{
By Elizabeth A. Pendleton, E. Robert Thieler, S. and Jeffress Williams
}

\begin{abstract}
A coastal vulnerability index (CVI) was used to map the relative vulnerability of the coast to future sealevel rise within War in the Pacific National Historical Park (NHP) on the island of Guam. The CVI ranks the following in terms of their physical contribution to sea-level rise-related coastal change: geomorphology, regional coastal slope, rate of relative sea-level rise, historical shoreline change rates, mean tidal range and mean significant wave height. The rankings for each input variable were combined, and an index value calculated for 200-meter grid cells covering the park. The CVI highlights those regions where the physical effects of sea-level rise might be the greatest. This approach combines the coastal system's susceptibility to change with its natural ability to adapt to changing environmental conditions, yielding a quantitative, although relative, measure of the park's natural vulnerability to the effects of sea-level rise. The CVI provides an objective technique for evaluation and long-term planning by scientists and park managers. War in the Pacific NHP consists of sand beaches and rock headlands. The areas within War in the Pacific NHP that are likely to be most vulnerable to sea-level rise are areas of unconsolidated sediment where coastal slope is lowest and wave energy is high.
\end{abstract}

\section{Introduction}

The National Park Service (NPS) is responsible for managing nearly 12,000 km (7,500 miles) of shoreline along oceans and lakes. In 2001, the U.S. Geological Survey (USGS), in partnership with the NPS Geologic Resources Division, began conducting hazard assessments of future sea-level change by creating maps to assist NPS in managing its valuable coastal resources. This report presents the results of a vulnerability assessment for War in the Pacific National Historical Park on Guam, highlighting areas that are likely to be most affected by future sealevel rise.

Global sea level has risen approximately 18 centimeters (7.1 inches) in the past century (Douglas, 1997). Climate models predict an additional rise of $48 \mathrm{~cm}$ (18.9 in.) by 2100 (IPCC, 2001), which is more than double the rate of rise for the 20th century. Potential coastal impacts of sea-level rise include shoreline erosion, saltwater intrusion into groundwater aquifers, inundation of wetlands and estuaries, and threats to cultural and historic resources as well as infrastructure. Predicted accelerated global sea-level rise has generated a need in coastal geology to determine the likely response of a coastline to sea-level rise. However, an accurate and quantitative approach to predicting coastal change is difficult to establish. Even the kinds of data necessary to predict shoreline response are the subject of scientific debate. A number of predictive approaches have been proposed (National Research Council, 1990 and 1995), including: 1) extrapolation of historical data (e.g., coastal erosion rates), 2) static inundation modeling, 3) application of a simple geometric model (e.g., the Bruun Rule), 4) application of a sediment dynamics/budget model, or 5) Monte Carlo (probabilistic) simulation based on parameterized physical forcing variables. However, each of these approaches has inadequacies or can be invalid for certain applications (National Research Council, 1990). Additionally, shoreline response to sea-level change is further complicated by human modification of the natural coast such as beach nourishment projects, and engineered structures such as seawalls, revetments, groins, and jetties. Understanding how a natural or modified coast will respond to sea-level change is essential to preserving vulnerable coastal resources.

The primary challenge in predicting shoreline response to sea-level rise is quantifying the important variables that contribute to coastal evolution in a given area. In order to address the multi-faceted task of predicting sea-level rise impact, the USGS has implemented a methodology to identify areas that may be most vulnerable to future sea-level rise (see Hammar-Klose and Thieler, 2001). This technique uses different ranges of vulnerability 
(low to very high) to describe a coast's susceptibility to physical change as sea level rises. The vulnerability index determined here focuses on six variables that strongly influence coastal evolution:

1. Geomorphology

2. Historical shoreline change rate

3. Regional coastal slope

4. Relative sea-level change

5. Mean significant wave height

6. Mean tidal range

These variables can be divided into two groups: 1) geologic variables and 2) physical process variables. The geologic variables are geomorphology, historic shoreline change rate, and coastal slope; they account for a shoreline's relative resistance to erosion, long-term erosion/accretion trend, and its susceptibility to flooding, respectively. The physical process variables include significant wave height, tidal range, and sea-level change, all of which contribute to the inundation hazards of a particular section of coastline over time scales from hours to centuries. A relatively simple vulnerability ranking system (Table 1) allows the six variables to be incorporated into an equation that produces a coastal vulnerability index (CVI). The CVI can be used by scientists and park managers to evaluate the likelihood that physical change may occur along a shoreline as sea level continues to rise.

Additionally, NPS staff will be able to incorporate information provided by this vulnerability assessment technique into general management plans.

\section{Data Ranking}

Table 1 shows the six variables described in the Introduction, which include both quantitative and qualitative information. The five quantitative variables are assigned a vulnerability ranking based on their actual values, whereas the non-numerical geomorphology variable is ranked qualitatively according to the relative resistance of a given landform to erosion. Shorelines with erosion/accretion rates between -1.0 and $+1.0 \mathrm{~m} / \mathrm{yr}$ are ranked as being of moderate vulnerability in terms of that particular variable. Increasingly higher erosion or accretion rates are ranked as correspondingly higher or lower vulnerability. Regional coastal slopes range from very high vulnerability, $<4.59$ percent, to very low vulnerability at values $>14.7$ percent. The rate of relative sea-level change is ranked using the modern rate of eustatic rise $(1.8 \mathrm{~mm} / \mathrm{yr})$ as very low vulnerability. Since this is a global or "background" rate common to all shorelines, the sea-level rise ranking reflects primarily local to regional isostatic or tectonic adjustment. Mean wave height contributions to vulnerability range from very low $(<1.1 \mathrm{~m})$ to very high $(>2.6 \mathrm{~m})$. Tidal range is ranked such that microtidal $(<1 \mathrm{~m})$ coasts are very high vulnerability and macrotidal $(>6 \mathrm{~m})$ coasts are very low vulnerability.

\section{War in the Pacific National Historical Park}

The Mariana Archipelago is an island arc chain that exists as a result of the subduction of the Pacific Plate beneath the Philippine Plate (http://volcano.und.edu/vwdocs/volc_images/southeast_asia/mariana/basic_ geology.html). Guam lies about 5,300 km ( 3,300 miles) southwest of Hawaii, and it is the largest and southernmost island of the Marianas (Figure 1). Guam is composed of two distinct geologic units, volcanic mountains to the south and a limestone plateau in the north. Most of the island is surrounded by a fringing coral reef that helps buffer the coast from open Pacific Ocean waves and storms. However, coral reefs on Guam are vulnerable not only to expected sea-level rise acceleration, but also to storm damage, increased water temperatures, coral diseases, and land runoff and sedimentation. Because coral reef systems need light to grow, sea-level rise will likely result in death to ecosystems at the depth limit of light penetration (Hoegh-Guldberg, 1999). Some scientists would argue that sealevel rise alone could result in increased coral growth by providing more 'headroom' for ecosystems that have reached their limit of vertical growth. Although this could be a scenario, sea-level rise is likely to be accompanied by increased water temperatures and changes in salinity, which could further damage or stress coral ecosystems. 
Further, slow growing corals may not be able to keep pace with potential increases in the rate of sea-level rise (Hoegh-Guldberg 1999; Graus, 1998).

Other natural hazards that impact coastal evolution on Guam include tropical cyclones (Richmond and Jaffe, 1991) and tsunamis (Lander and others, 2002). In December 2002 super typhoon Pongsona resulted in severe damage to the park Visitor's Center, and in 2004 super typhoon Chaba caused extensive overwash and erosion along the park shoreline.

Guam supports a diverse ecosystem that War in the Pacific National Historical Park is preserving. In addition to the many natural resources along this coast, there are significant cultural resources within the park as old as 2000 years and extend through Guam's role in the Pacific Theater of World War II (for more information on the park's historical and cultural resources please see: http://www.nps.gov/wapa/indepth/.

\section{Methodology}

In order to develop a database for a park-wide assessment of coastal vulnerability, data for each of the six variables mentioned above were gathered from state and federal agencies (Table 2). The database is based on that used by Thieler and Hammar-Klose (1999) and loosely follows an earlier database developed by Gornitz and White (1992). A comparable assessment of the sensitivity of the Canadian coast to sea-level rise is presented by Shaw and others (1998).

The database was constructed using a 1:3780-scale shoreline for Guam that was obtained from NOAA/NOS's Biogeography Program (http://biogeo.nos.noaa.gov/projects/mapping/pacific/territories/data/). Data for each of the six variables (geomorphology, shoreline change, coastal slope, relative sea-level rise, significant wave height, and tidal range) were added to the shoreline attribute table using a 200-meter grid (Figure 2). Next each variable in each grid cell was assigned a vulnerability value from 1-5 ( 1 is very low vulnerability, 5 is very high vulnerability) based on the potential magnitude of its contribution to physical changes on the coast as sea level rises (Table 1).

\section{Geologic Variables}

The geomorphology variable expresses the relative erodibility of different landform types (Table 1). These data were derived using the 2002-2003 IKONOS imagery provided by the Pacific Islands GIS Project and NOAA/NOS (http://www.csc.noaa.gov/islandsgis/resources.html). In addition, field visits were made within accessible locations of the park to verify the geomorphologic classification (Figure 3 A-B and Figure 4 A-C). War in the Pacific NHP consists of geomorphology types, that include high vulnerability rubble to rocky shoreline skirted by fringing reef and very high vulnerability sand beaches with fringing reef (Figure 5).

Shoreline erosion and accretion rates for War in the Pacific NHP were calculated using digitized shorelines from 1966 and 2002/2003 (Table 2). Shoreline rates of change (m/yr) were calculated at $50 \mathrm{~m}$ intervals (transects) along the coast using Digital Shoreline Analysis System (DSAS) software (http://woodshole.er.usgs.gov/project-pages/dsas/) to derive the rate of shoreline change. The change rates for each transect within each grid cell were averaged to determine the shoreline change value used here, with positive numbers indicating accretion and negative numbers indicating erosion. Shoreline change rates within the park are all in the moderate vulnerability category, which is between $-1 \mathrm{~m} / \mathrm{yr}$ and $+1 \mathrm{~m} / \mathrm{yr}$. The rocky portions of the shoreline have not changed since 1966, There has been some erosion along Asan Beach and other sandy areas, although rates still lie within $+/-1 \mathrm{~m} / \mathrm{yr}$ (Figure 6).

Regional coastal slope is an indication of the relative vulnerability to inundation and the potential rapidity of shoreline retreat because low-sloping coastal regions should retreat faster than steeper regions (Pilkey and Davis, 1987). The regional slope of the coastal zone was calculated from a grid of topographic and bathymetric elevations extending $2 \mathrm{~km}$ landward and seaward of the shoreline. Elevation data were obtained from the National Geophysical Data Center (NGDC) as gridded topographic and bathymetric elevations at 0.1-meter vertical resolution for 1-minute grid cells. These data were supplemented with DEM data from NOAA's Biogeography Program and SHOALS (Scanning Hydrographic Operational Airborne Lidar Survey) data (Table 2). Regional 
coastal slopes for War in the Pacific National Historical Park fall within the very low to very high vulnerability category $(<4.55 \%->14.7 \%)$ (Figure 7$)$.

\section{Physical Process Variables}

The determination of relative sea-level change variable is derived from the change in annual mean water elevation over time as measured at tide gauge stations along the coast. The rate of sea-level rise for Guam is $0.10+/$ $0.90 \mathrm{~mm} / \mathrm{yr}$ based on 52 years of data (Zervas, 2001). This variable inherently includes both eustatic sea-level rise as well as regional sea-level rise due to isostatic and tectonic adjustments of the land surface. Relative sea-level change data are a historical record, and thus portray only the recent sea-level trend ( $<150$ years). Relative sea-level rise for War in the Pacific National Historical Park falls within the very low vulnerability category based on water elevation data in Guam (Figure 8).

Mean significant wave height is used here as a proxy for wave energy which drives the coastal sediment budget. Wave energy is directly related to the square of wave height;

$$
E=1 / 8 \rho g H^{2}
$$

where $E$ is energy density, $H$ is wave height, $\rho$ is water density and $g$ is acceleration due to gravity. Thus, the ability to mobilize and transport coastal sediments is a function of wave height squared. In this report, we use historical mean significant wave height data for the period 1990-1993 obtained from the National Data Buoy Center (http://www.ndbc.noaa.gov/). Buoy station 52009 is located at $13.2 \mathrm{~N} 144.5 \mathrm{~W}$ with mean significant wave heights at $2.1 \mathrm{~m}$. The Asan Beach Unit is ranked as moderate vulnerability with respect to wave heights; however, mean significant wave height is ranked as low vulnerability within the Agat Unit because this section of coast is partially sheltered from the dominant wave approach by the Orote Peninsula (Figure 9).

Tidal range is linked to both permanent and episodic inundation hazards. Tide range data were obtained from a NOAA/NOS published benchmark in Apra Harbor, Guam. Mean tidal range was $0.495 \mathrm{~m}$, therefore War in the Pacific NHP is classified as very high vulnerability $(<1 \mathrm{~m})$ with respect to tidal range (Figure 10).

\section{Coastal Vulnerability Index}

The coastal vulnerability index (CVI) presented here is the same as that used in Thieler and Hammar-Klose (1999) and is similar to that used in Gornitz and others (1994), as well as to the sensitivity index employed by Shaw and others (1998). The CVI allows the six variables to be related in a quantifiable manner that expresses the relative vulnerability of the coast to physical changes due to future sea-level rise. This method yields numerical data that cannot be equated directly with particular physical effects. It does, however, highlight areas where the various effects of sea-level rise may be the greatest. Once each section of coastline is assigned a vulnerability value for each specific data variable, the coastal vulnerability index is calculated as the square root of the product of the ranked variables divided by the total number of variables;

$\mathrm{CVI}=\sqrt{\frac{\left(a^{*} b^{*} c^{*} d^{*} e^{*} f\right)}{6}}$

where, $\mathrm{a}=$ geomorphology, $\mathrm{b}=$ shoreline erosion/accretion rate, $\mathrm{c}=$ coastal slope, $\mathrm{d}=$ =relative sea-level rise rate, $\mathrm{e}=$ mean significant wave height, and $\mathrm{f}=$ mean tide range. The calculated CVI value is then divided into quartile ranges to highlight different vulnerabilities within the park. The numeric CVI values that correspond to a specific vulnerability index (low - very high) are unique to Pacific National Historical Park, and are not comparable to CVI ranges in other parks where the CVI has been employed (i.e., very high vulnerability means the same among parks; it's the numeric values that differ, such that a numeric value that equals very high vulnerability in one park may equal moderate vulnerability in another). To compare vulnerability among coastal parks, the national-scale studies should be used (Thieler and Hammar-Klose, 1999, 2000a, and 2000b). This approach best describes and highlights the vulnerability specific to each park. 


\section{Results}

The CVI values calculated for Guam range from 5.0 to 10.0. The mean CVI value is 7.10; the mode is 10.0 and the median is 6.12 . The standard deviation is 1.88 . The 25 th, 50th, and 75 th percentiles are $5.5,7.0$ and 8.75 , respectively.

Figure 11 shows a map of the coastal vulnerability index for War in the Pacific NHP. The CVI scores are divided into low, moderate, high, and very high-vulnerability categories based on the quartile ranges and visual inspection of the data. CVI values below 5.5 are assigned to the low vulnerability category. Values from 5.5 to 7.0 are considered moderate vulnerability. High-vulnerability values lie between 7.01 and 8.75 . CVI values above 8.75 are classified as very high vulnerability. Figure 12 shows the percentage of War in the Pacific NHP shoreline in each vulnerability category. Over $11 \mathrm{~km}$ (7 miles) of park shoreline is evaluated, and of this total, twenty-six percent of the mapped shoreline is classified as being at very high vulnerability due to future sea-level rise. Twenty percent is classified as high vulnerability, twenty percent as moderate vulnerability, and thirty-four percent as low vulnerability.

\section{Discussion}

The data within the coastal vulnerability index (CVI) show variability at different spatial scales (Figure 11). However, the ranked values for the physical process variables vary less over the extent of the shoreline. The value of the relative sea-level rise variable is constant at very low vulnerability for the entire study area. The significant wave height vulnerability is low to moderate. The tidal range is very high vulnerability $(<1.0 \mathrm{~m})$ for all of the War in the Pacific NHP shoreline.

The geologic variables show the most spatial variability and thus have the most influence on CVI variability (Figure 11). Geomorphology in the park includes very high vulnerability sandy beach shoreline with fringing reef, and high vulnerability rubble to rocky shoreline with fringing reef (Figure 5). Vulnerability assessment based on shoreline change rate is constant at moderate vulnerability. Regional coastal slope is classified as very low to very high vulnerability (Figure 7).

The most influential variables in the CVI are geomorphology, regional coastal slope, and wave energy; therefore they may be considered the dominant factors controlling how Guam will evolve as sea level rises.

\section{Conclusions}

The coastal vulnerability index (CVI) provides insight into the relative potential of coastal change due to future sea-level rise. The maps and data presented here can be viewed in at least two ways:

1) as an indication of where physical changes are most likely to occur as sea level continues to rise; and

2) as a planning tool for the War in the Pacific National Historical Park.

As ranked in this study, geomorphology, regional coastal slope, and wave energy are the most important variables in determining the spatial variability of the CVI for Guam. Tidal range, shoreline change, and sea-level rise rate do not contribute to the spatial variability in the coastal vulnerability index.

War in the Pacific National Historical Park preserves a dynamic natural environment, which must be understood in order to be managed properly. The CVI is one way that park managers can assess objectively the natural factors that contribute to the evolution of the coastal zone, and thus how the park may evolve in the future. The CVI ranges (low - very high) reported here apply specifically to War in the Pacific NHP, and are not comparable to CVI ranges in other parks where the CVI has been employed. We feel this approach best describes and highlights the vulnerability specific to War in the Pacific NHP. 


\section{References}

Douglas, B.C., 1997, Global sea rise, a redetermination: Surveys in Geophysics, v. 18, p. 279-292.

Gornitz, V., and White, T.W., 1992, A coastal hazards database for the U.S. West Coast: ORNL/CDIAC-81, NDP-043C, 0ak Ridge National Laboratory, Oak Ridge, Tenn.

Gornitz, V.M., Daniels, R.C., White, T.W., and Birdwell, K.R., 1994, The development of a coastal vulnerability assessment database, vulnerability to sea-level rise in the U.S. southeast: Journal of Coastal Research, Special Issue No. 12, p. 327-338.

Graus, R.R. and Macintyre I.G., 1998, Global warming and the future of Caribbean coral reefs: Carbonates and Evaporites, v. 13, no. 1, p. 43-47.

Hammar-Klose, E.S., and Thieler, E.R., 2001, Coastal vulnerability to sea-level rise; A preliminary database for the U.S. Atlantic, Pacific, and Gulf of Mexico coasts: U.S. Geological Survey, Digital Data Series, DDS-68, CD-ROM. Online

Hoegh-Guldberg, 0., 1999, Climate change, coral bleaching and the future of the world's coral reefs: Marine Freshwater Research, v. 50, p. $839-866$.

IPCC (Intergovernmental Panel on Climate Change), 2001, Climate Change 2001, in Houghton, J.T., Ding, Y., Griggs, D.J., Noguer, M., van der Linden, P.J., and Xiaosu, D., eds., The Scientific Basis; Contribution of Working Group I to the Third Assessment Report of the Intergovernmental Panel on Climate Change (IPCC): Cambridge, University Press, U.K., 944 p. (Also available at http://www.ipcc.ch/)

Lander, J.F., Whiteside, L.S., and Hattori P., 2002, The Tsunami history of Guam, 1849-1993: The International Journal fo the Tsunami Society, v. 20, no. 3, p. 158-174.

National Research Council, 1990, Managing Coas tal Erosion, Washington: National Academy Press, 163 p.

National Research Council, 1995, Beach Nourishment and Protection, Washington: National Academy Press, 334 p.

Pilkey, O.H., and Davis, T.W., 1987, An analysis of coastal recession models, North Carolina coast, in Nummedal, D., Pilkey, 0.H., and Howard, J.D., eds., Sea-level Fluctuation and Coastal Evolution: SEPM (Society for Sedimentary Geology) Special Publications No. 41, Tulsa, 0kla., p. 59-68.

Richmond, B.M., and Jaffe, B.E., 1991, Typhoon Russ Effects on the Shoreline of Guam: U.S. Geological Survey Open-File Report 91-571, $39 \mathrm{p}$.

Shaw, J., Taylor, R.B., Forbes, D.L., Ruz, M.H., and Solomon, S., 1998, Sensitivity of the Canadian Coast to Sea-Level Rise: Geological Survey of Canada Bulletin 505, $114 \mathrm{p}$.

Thieler, E.R., and Hammar-Klose, E.S., 1999, National assessment of coastal vulnerability to sea-level rise, U.S. Atlantic Coast: U.S. Geological Survey Open-File Report 99-593, 1 sheet. Online

Thieler, E.R., and Hammar-Klose, E.S., 2000a, National assessment of coastal vulnerability to sea-level rise, U.S. Pacific Coast: U.S. Geological Survey Open-File Report 00-178, 1 sheet. Online

Thieler, E.R., and Hammar-Klose, E.S., 2000b, National assessment of coastal vulnerability to sea-level rise, U.S. Gulf of Mexico Coast: U.S. Geological Survey Open-File Report 00-179, 1 sheet. Online

Zervas, C., 2001, Sea Level Variations of the United States 1854-1999: NOAA Technical Report NOS CO-OPS 36, 201 p. 


\section{List of Figures}

Figure 1. Location of War in the Pacific National Historical Park, Guam.

Figure 2. Shoreline grid for War in the Pacific National Historical Park. Each cell is approximately 200 meters of shoreline and represents a shoreline segment for which each variable is defined..

Figure 3. Photos of geomorphic features within the Asan Beach Unit of War in the Pacific National Historical Park. The map at the top shows the locations of photos $A$ and $B$.

Figure 4. Photos of geomorphic features within the Agat Unit of War in the Pacific National Historical Park. The map at the top left shows the locations of photos $A, B$ and $C$.

A) A close view of the limestone on Apaca Point, this area was classified as high vulnerability.

B) A view of the beach south of Apaca Point; this beach is very high vulnerability.

C) The beach at Ga'an Point is also very high vulnerability and one of the hard hit areas of super typhoon Chaba.

Figure 5. Coastal geomorphology for War in the Pacific National Historical Park. The colored shoreline represents the variations in coastal geomorphology within the park. War in the Pacific NHP consists of several geomorphic types, including high vulnerability rubble to rocky shoreline skirted by fringing reef and very high vulnerability sand beaches with fringing reef.

Figure 6. Shoreline change rates for War in the Pacific NHP. The colored shoreline represents the rate of shoreline erosion or accretion. All of War in the Pacific NHP is moderate vulnerability $(-1 \mathrm{~m} / \mathrm{yr}-+1 \mathrm{~m} / \mathrm{yr})$ with respect to shoreline change.

Figure 7. Regional coastal slope for War in the Pacific National Historical Park. The colored shoreline represents the regional slope of the land, $2 \mathrm{~km}$ landward and seaward of the shoreline. The Asan Beach Unit is low to very low vulnerability with respect to coastal slope because of the higher elevation upland behind the beach. Parts of the Agat Unit are higher vulnerability because of flat lying areas near the coast.

Figure 8. Rate of relative sea-level rise for War in the Pacific NHP. The colored shoreline represents the ranked rate of rise for Apra Harbor. All of War in the Pacific NHP is ranked as very low vulnerability with respect to relative sea-level rise.Figure 9. Vulnerability ranking for regional coastal slope of the National Park of American Samoa. The colored shoreline represents the regional slope of the land, $2 \mathrm{~km}$ landward and seaward of the shoreline. The low vulnerability areas with respect to coastal slope are primarily concentrated on Ta'u. Tutuila is moderate to high vulnerability, and Ofu and Olosega are mostly moderate to high vulnerability with a small area of low vulnerability along the north coast.

Figure 9. Mean significant wave heights for War in the Pacific National Historical Park based on NDBC data. The colored shoreline represents the mean significant wave heights within the park. The Asan Beach Unit is of moderate vulnerability with respect to wave heights; however, mean significant wave height is low vulnerability within the Agat Unit because this coastline is partially sheltered by the Orote Peninsula.

Figure 10. Mean Tidal Range for War in the Pacific National Historical Park. The colored shoreline represents the ranked mean tidal range based on a gage in Apra Harbor. All of War in the Pacific NHP is ranked as very high vulnerability with respect to tidal range.

Figure 11. Relative Coastal Vulnerability for War in the Pacific National Historical Park. The colored shoreline represents the relative coastal vulnerability index (CVI) determined from the six variables. The very high vulnerability shoreline is located along the sandy areas of the Agat Unit that have the lowest coastal slopes. The low vulnerability shoreline is located along the rocky parts of the coast with steep coastal slopes.

Figure 12. Percentage of Guam shoreline in each CVI category. 


\section{List of Tables}

Table 1. Ranges for Vulnerability Ranking of Variables on the Pacific Coast.

Table 2. Sources of Data 


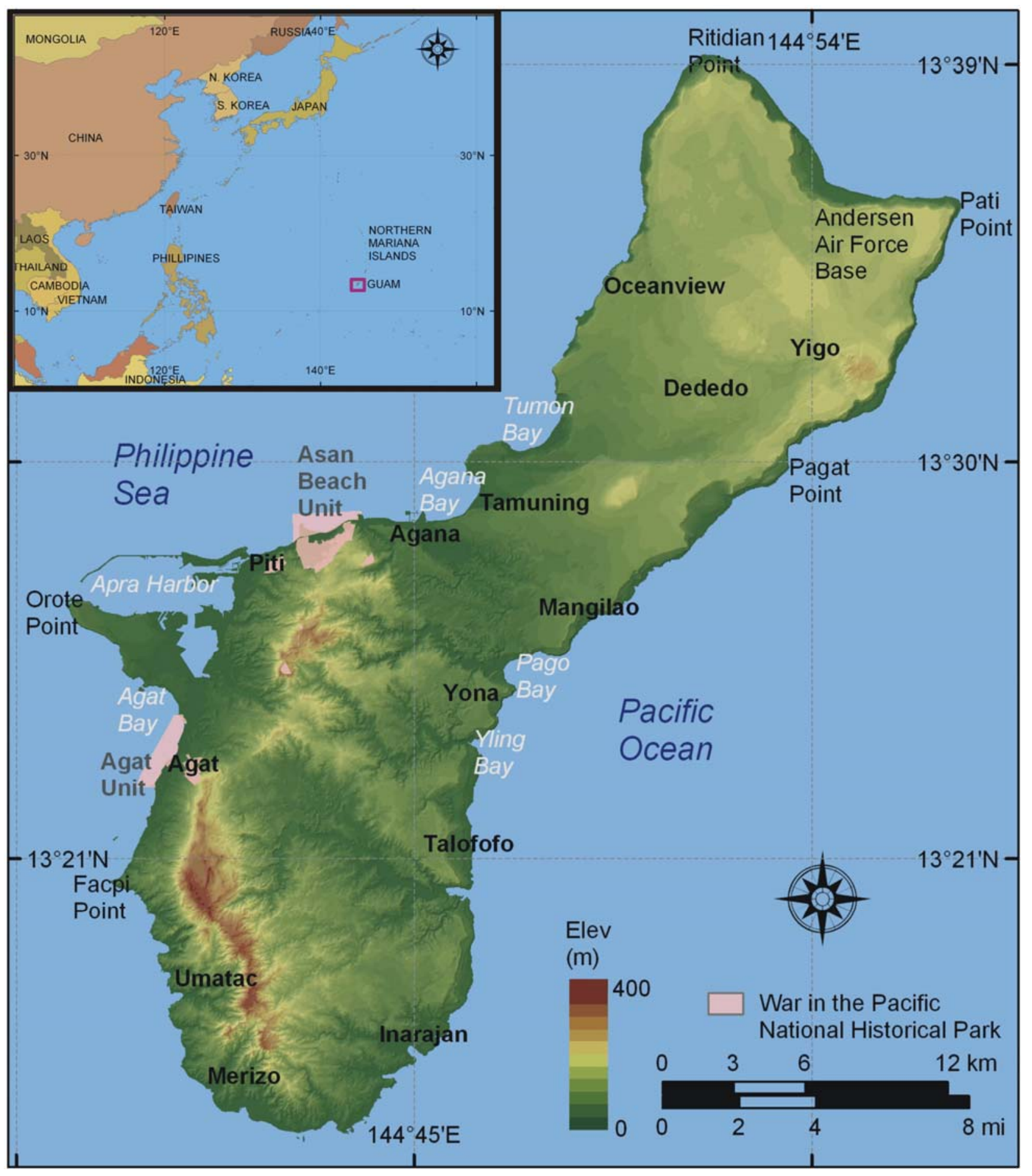

Figure 1. Location of War in the Pacific National Historical Park, Guam. 


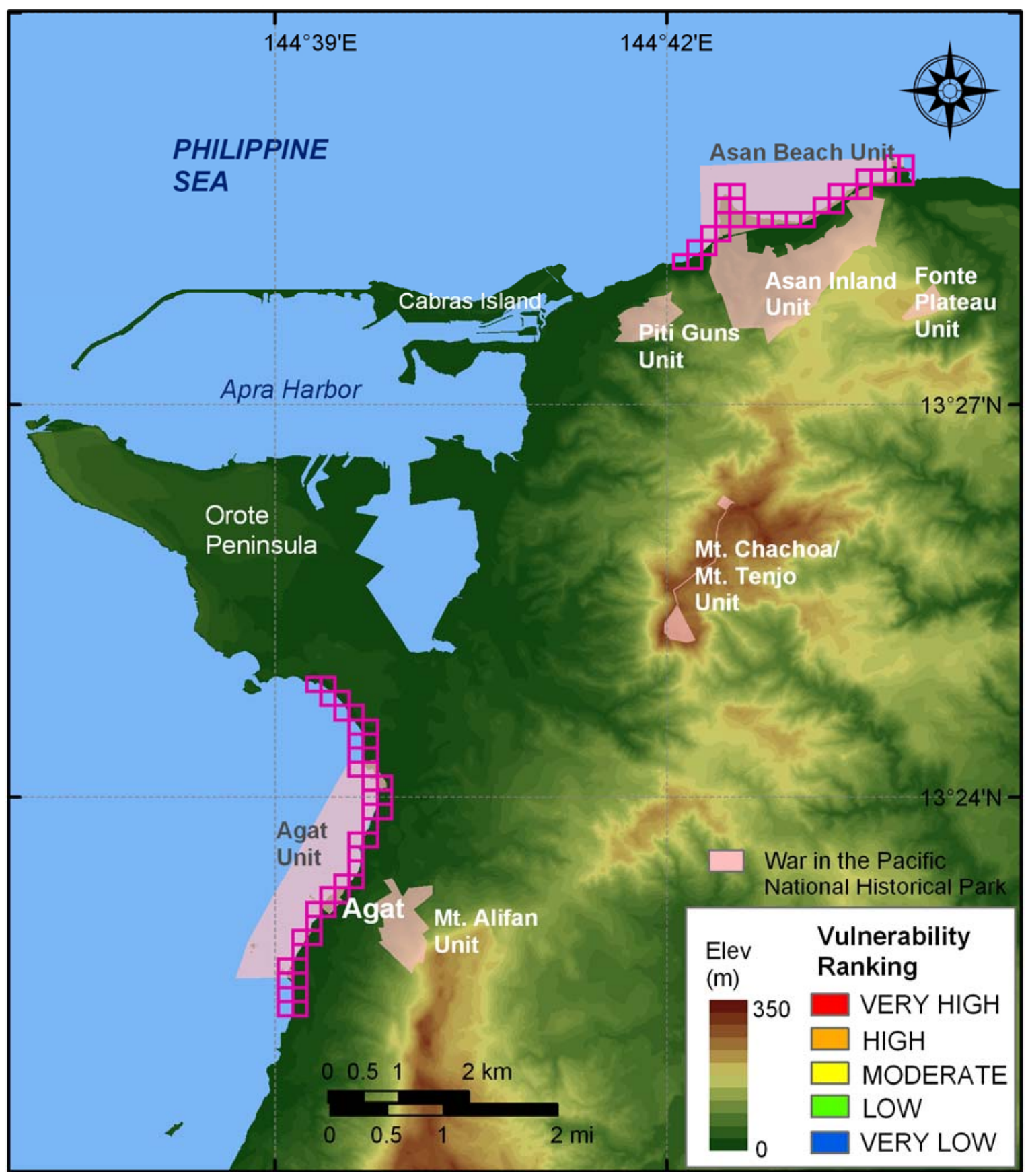

Figure 2. Shoreline grid for War in the Pacific National Historical Park. Each cell is approximately 200 meters of shoreline and represents a shoreline segment for which each variable is defined. 


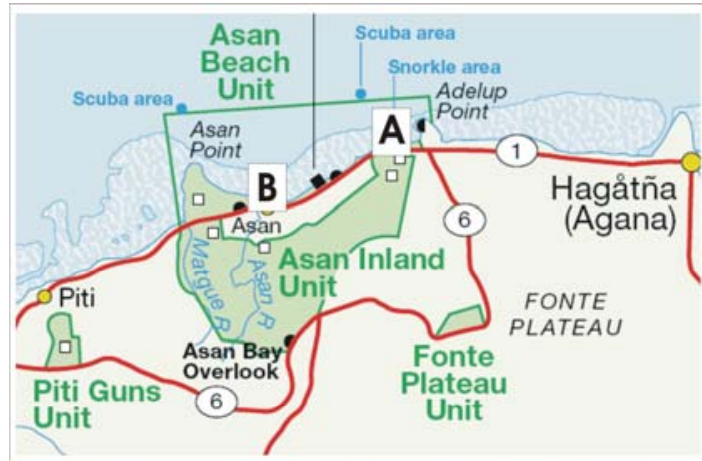

This figure is an excerpt from the NPS War in the Pacific National Historical Park map.
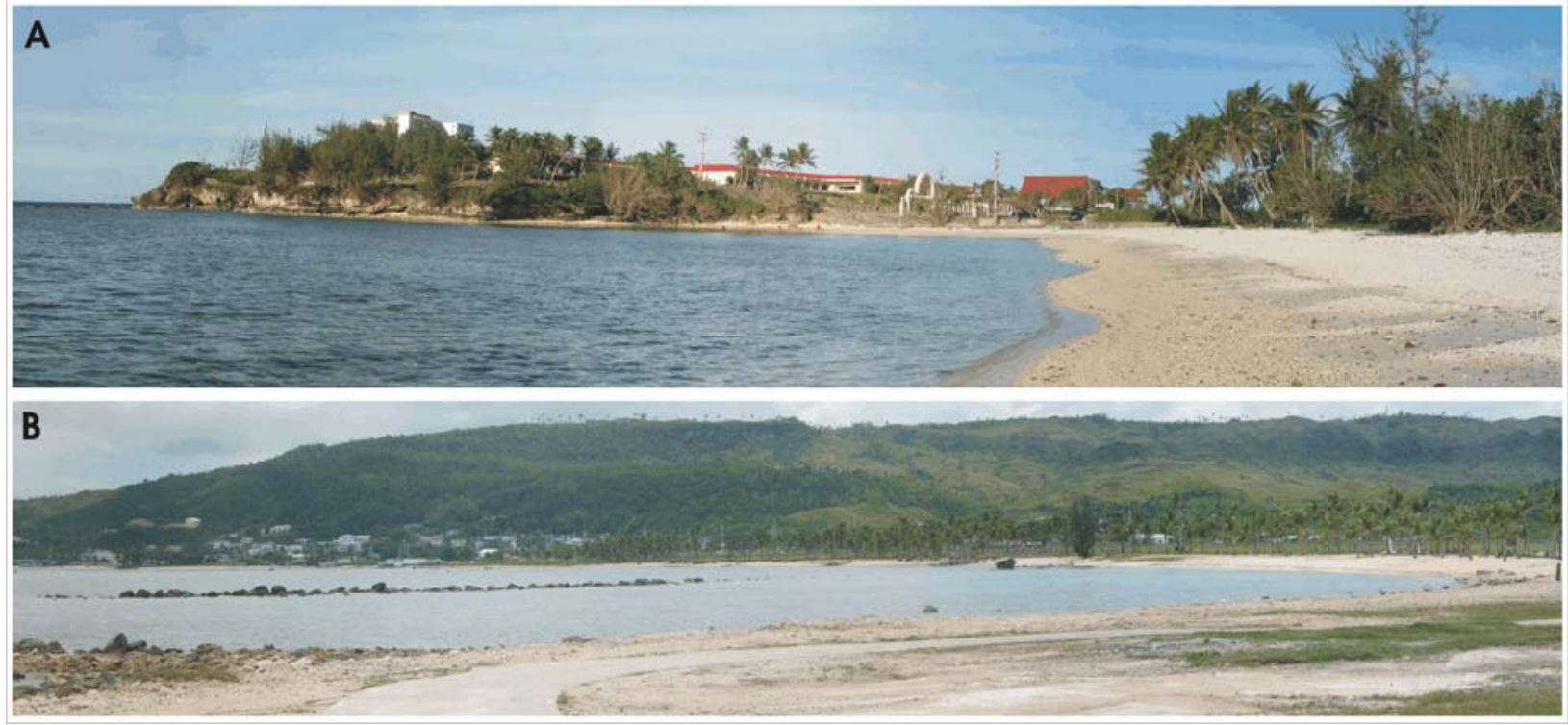

Figure 3 Photos of geomorphic features within the Asan Beach Unit of War in the Pacific National Historical Park. The map at the top shows the locations of photos $A$ and $B$.

A) A view of Adelup Point and the governor's mansion. Adelup Point was classified as high vulnerability.

B) A view of Asan Beach from near Asan Point. Asan beach was classified as very high vulnerability, and Asan Point was classified as high vulnerability. 


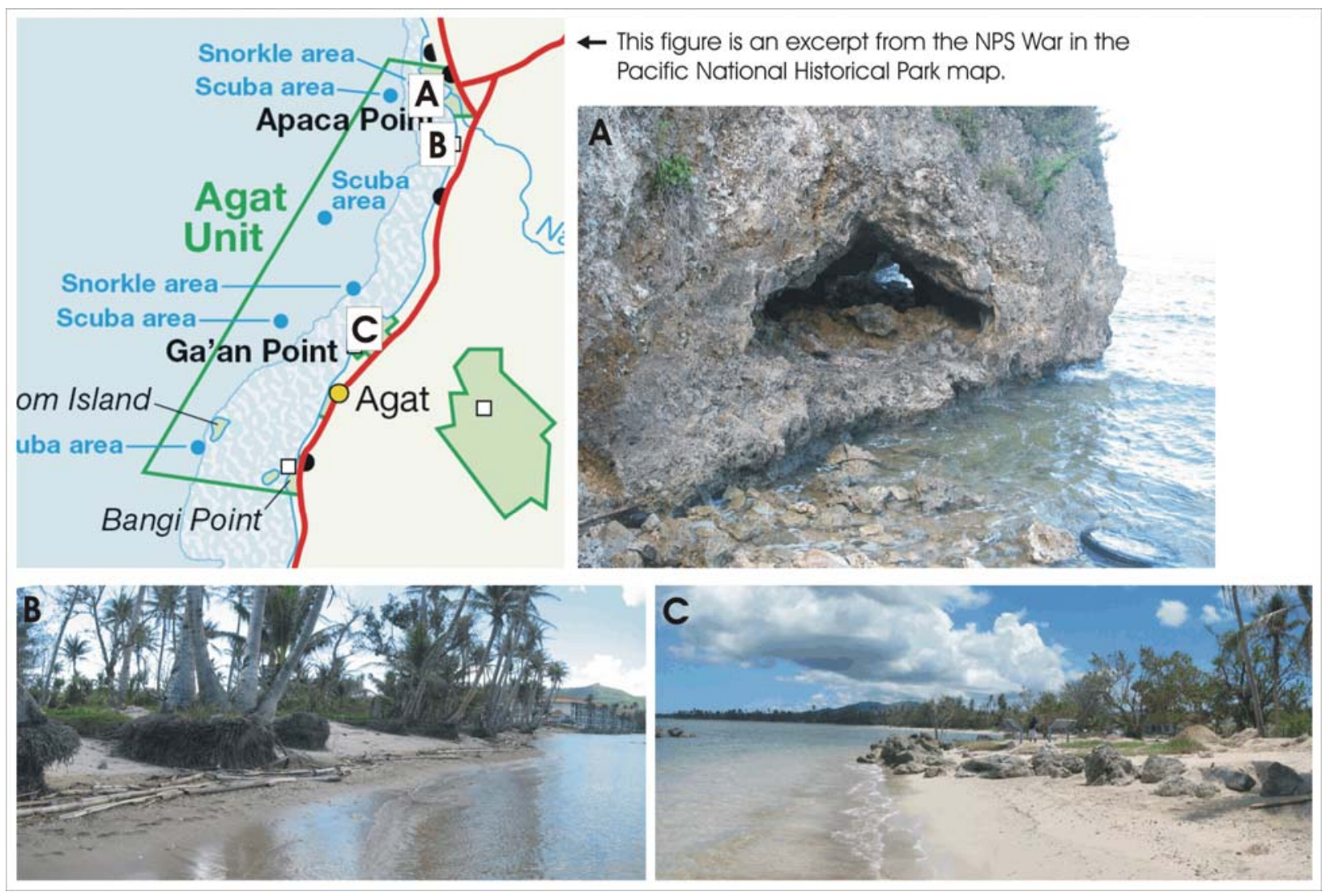

Figure 4. Photos of geomorphic features within the Agat Unit of War in the Pacific National Historical Park. The map at the top left shows the locations of photos $A, B$ and $C$.

A) A close view of the limestone on Apaca Point, this area was classified as high vulnerability.

B) A view of the beach south of Apaca Point; this beach is very high vulnerability.

C) The beach at Ga'an Point is also very high vulnerability and one of the hard hit areas of super typhoon Chaba. 


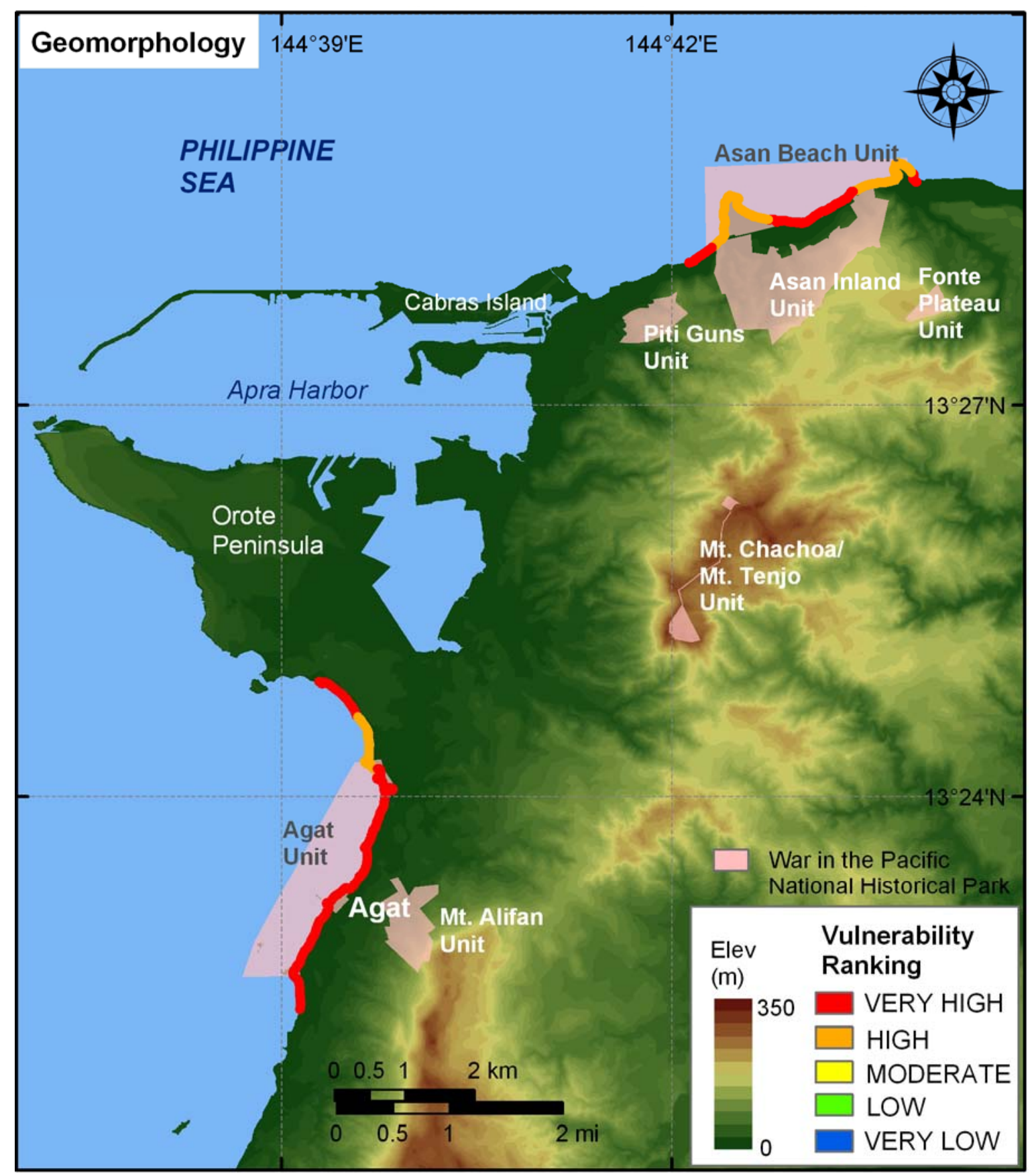

Figure 5. Coastal geomorphology for War in the Pacific National Historical Park. The colored shoreline represents the variations in coastal geomorphology within the park. War in the Pacific NHP consists of several geomorphic types, including high vulnerability rubble to rocky shoreline skirted by fringing reef and very high vulnerability sand beaches with fringing reef. 


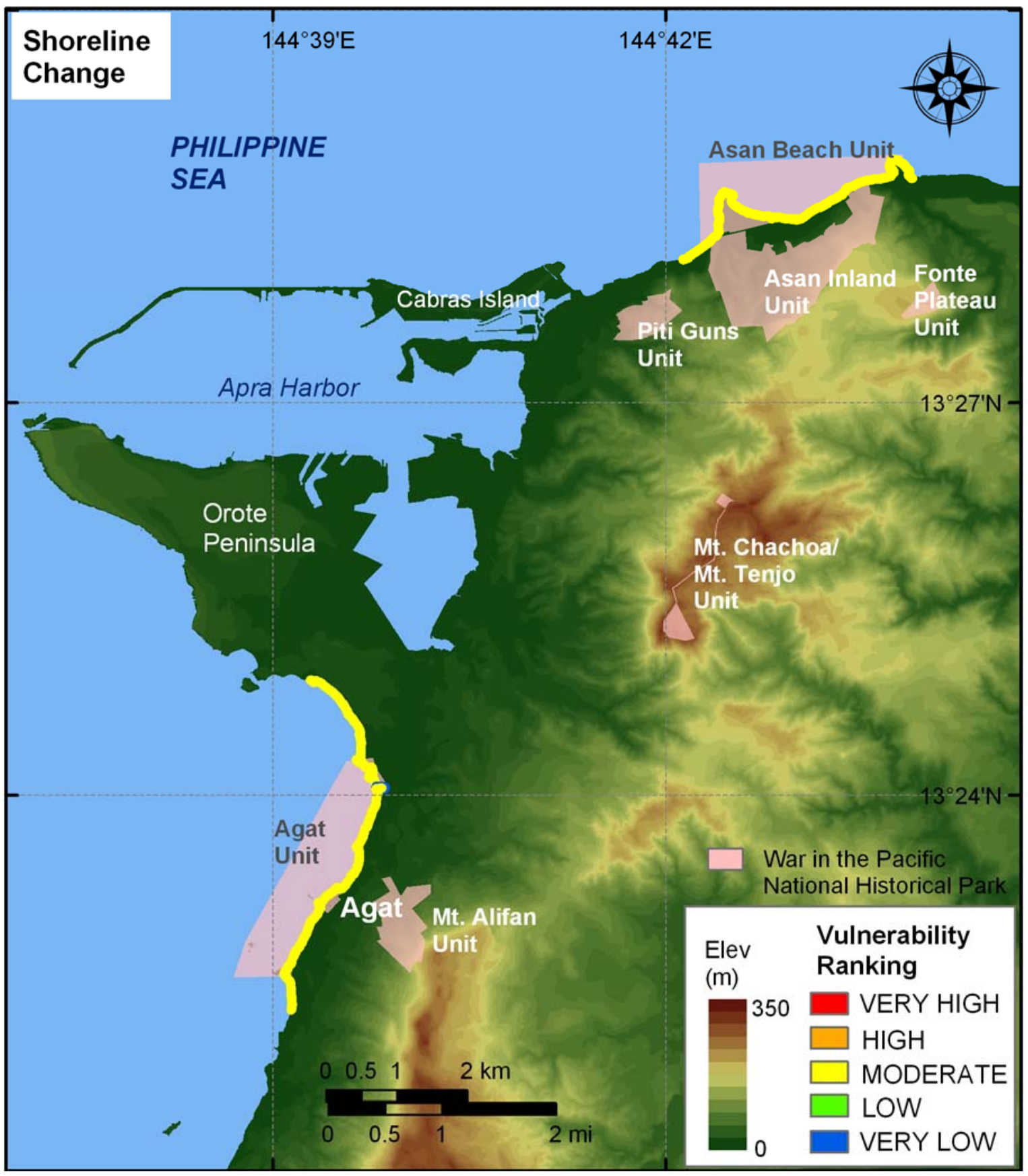

Figure 6. Shoreline change rates for War in the Pacific NHP. The colored shoreline represents the rate of shoreline erosion or accretion. All of War in the Pacific NHP is moderate vulnerability $(-1 \mathrm{~m} / \mathrm{yr}-+1 \mathrm{~m} / \mathrm{yr})$ with respect to shoreline change. 


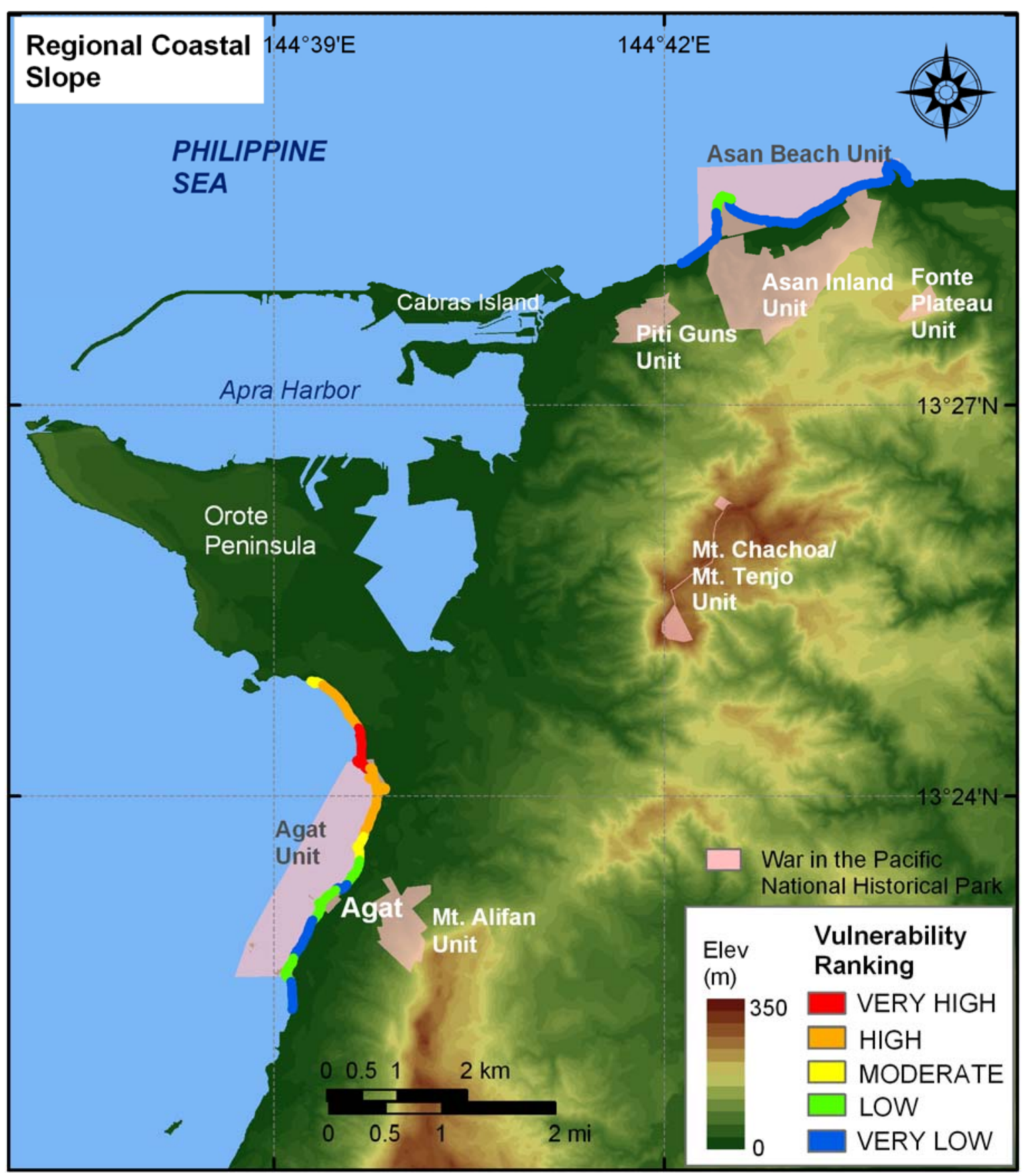

Figure 7. Regional coastal slope for War in the Pacific National Historical Park. The colored shoreline represents the regional slope of the land, $2 \mathrm{~km}$ landward and seaward of the shoreline. The Asan Beach Unit is low to very low vulnerability with respect to coastal slope because of the higher elevation upland behind the beach. Parts of the Agat Unit are higher vulnerability because of flat lying areas near the coast. 


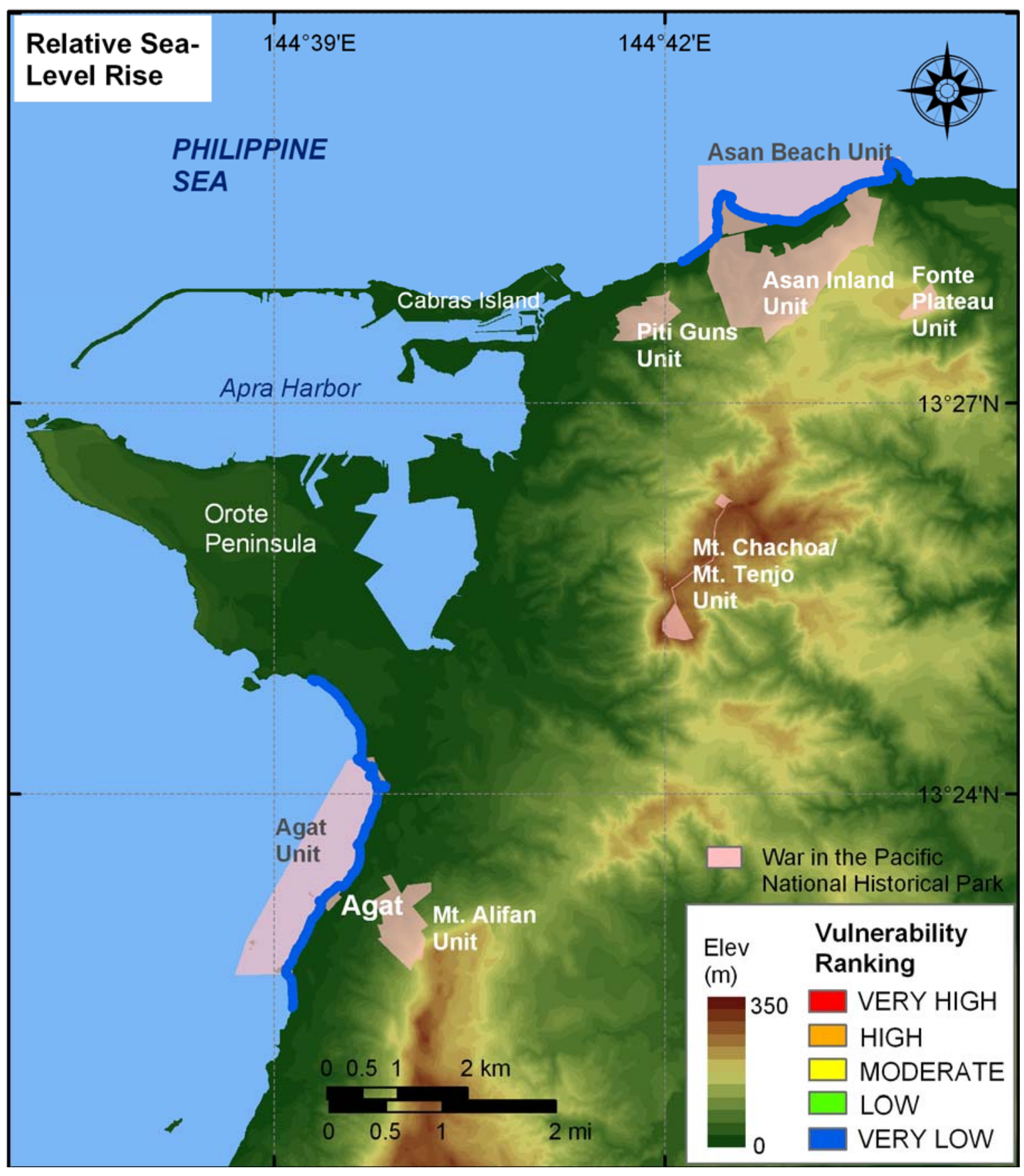

Figure 8. Rate of relative sea-level rise for War in the Pacific NHP. The colored shoreline represents the ranked rate of rise for Apra Harbor. All of War in the Pacific NHP is ranked as very low vulnerability with respect to relative sea-level rise. 


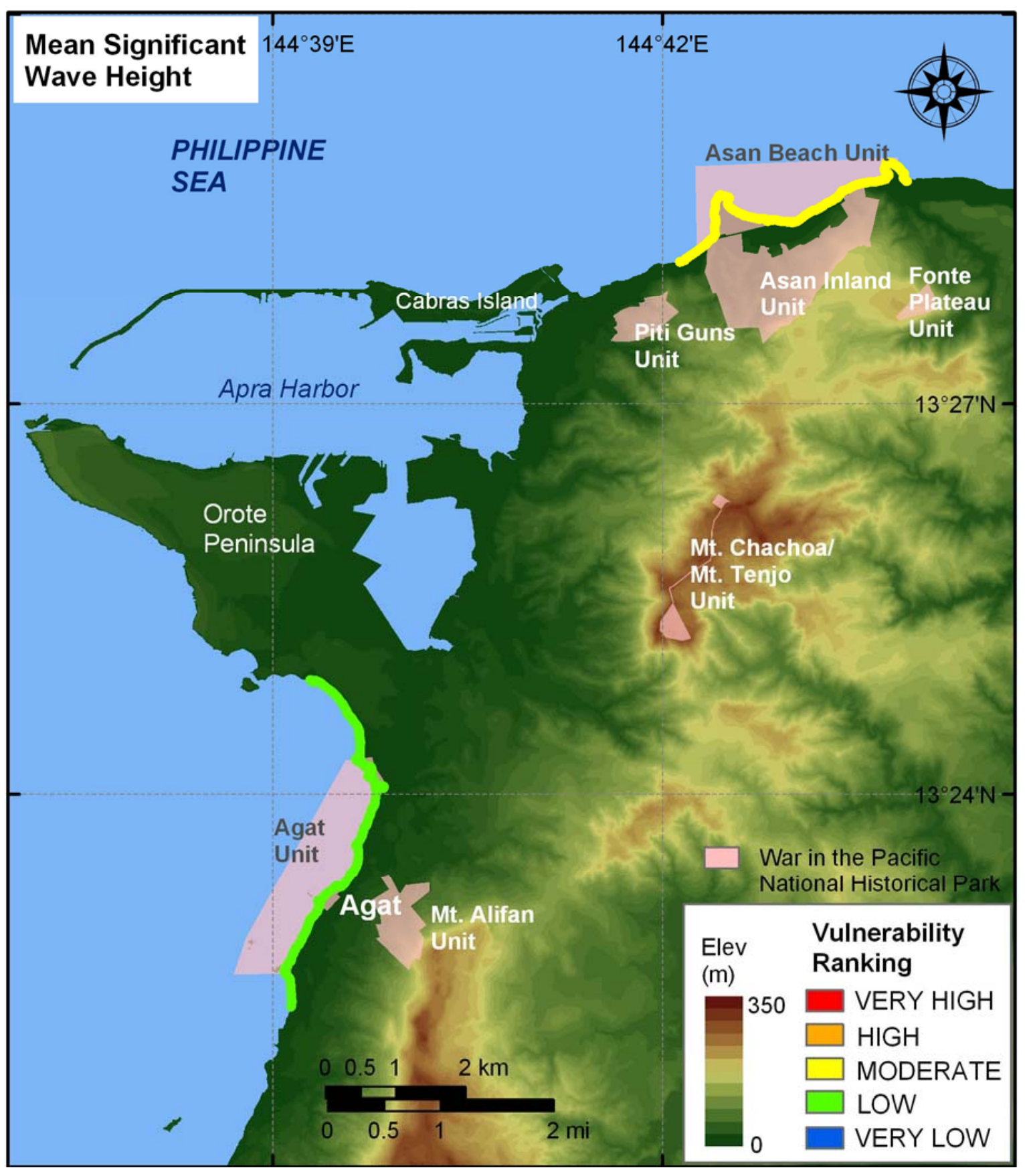

Figure 9. Mean significant wave heights for War in the Pacific National Historical Park based on NDBC data. The colored shoreline represents the mean significant wave heights within the park. The Asan Beach Unit is of moderate vulnerability with respect to wave heights; however, mean significant wave height is low vulnerability within the Agat Unit because this coastline is partially sheltered by the Orote Peninsula. 


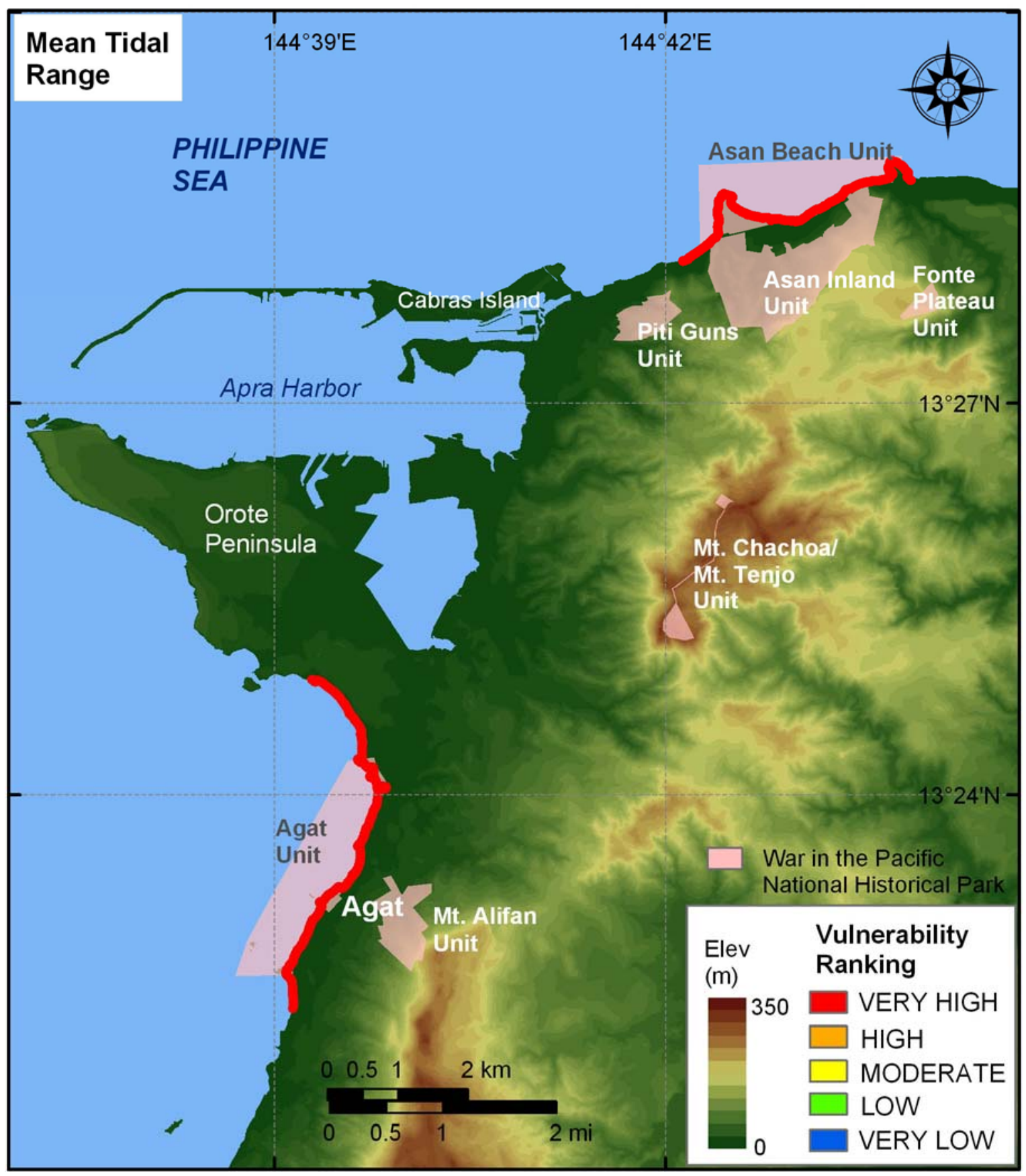

Figure 10. Mean Tidal Range for War in the Pacific National Historical Park. The colored shoreline represents the ranked mean tidal range based on a gage in Apra Harbor. All of War in the Pacific NHP is ranked as very high vulnerability with respect to tidal range. 


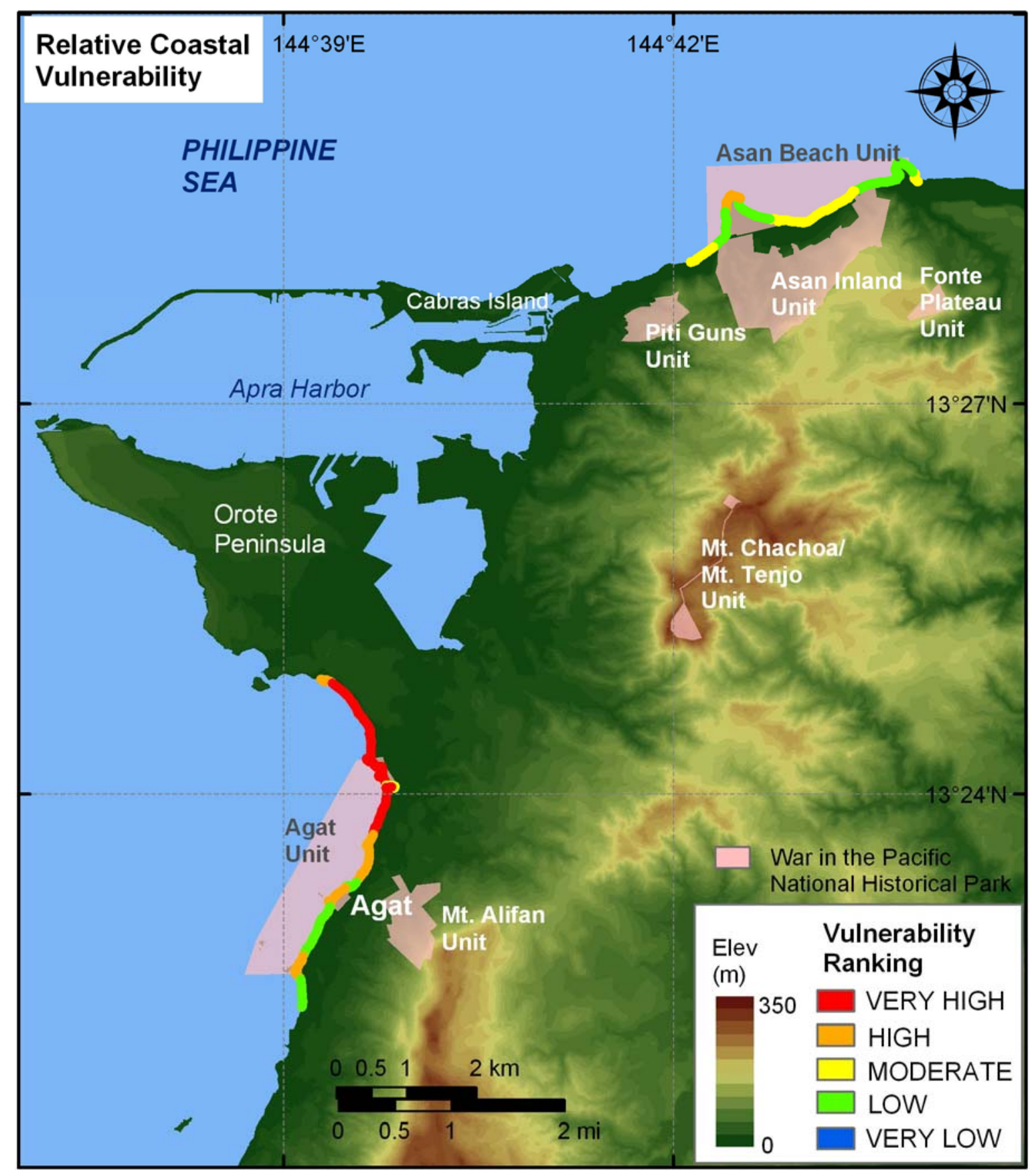

Figure 11. Relative Coastal Vulnerability for War in the Pacific National Historical Park. The colored shoreline represents the relative coastal vulnerability index (CVI) determined from the six variables. The very high vulnerability shoreline is located along the sandy areas of the Agat Unit that have the lowest coastal slopes. The low vulnerability shoreline is located along the rocky parts of the coast with steep coastal slopes. 


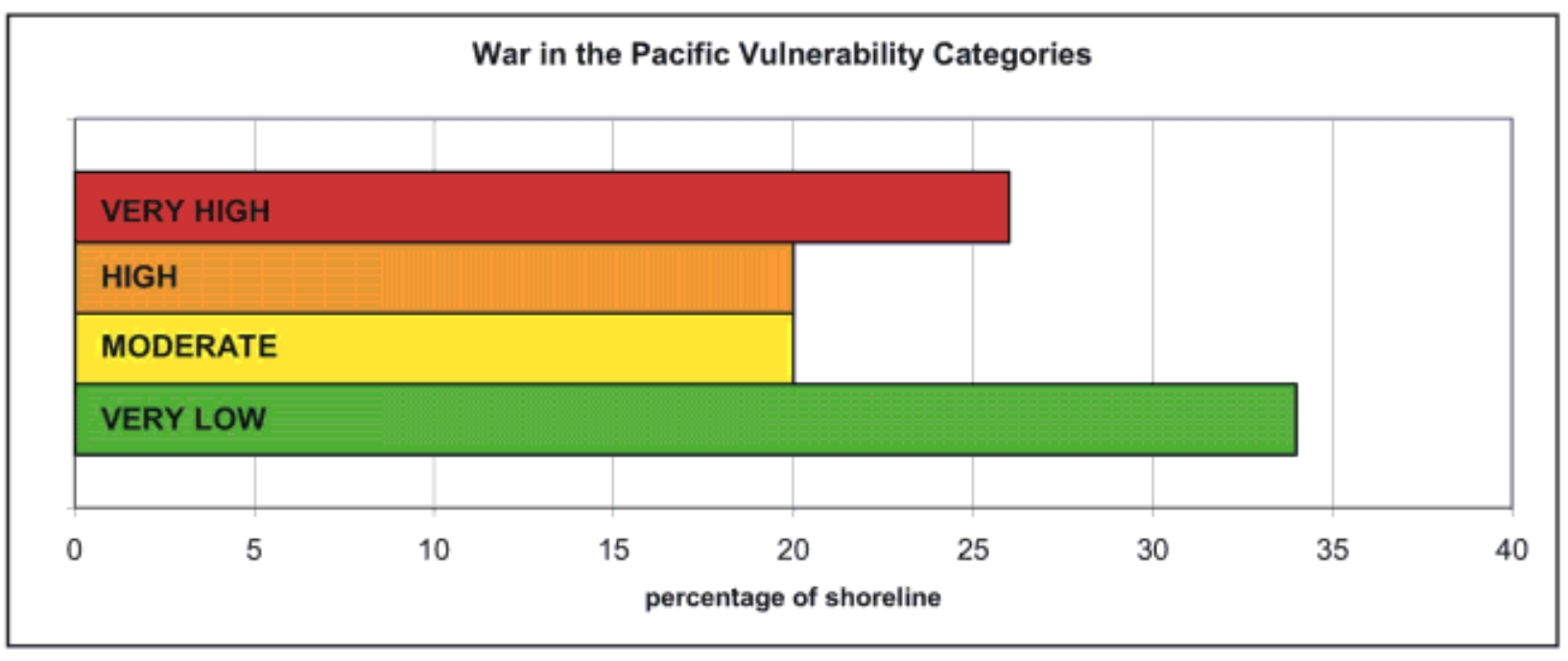

Figure 12. Percentage of Guam shoreline in each CVI category. 
Table 1: Ranges for Vulnerability Ranking of Variables on the Pacific Coast.

\begin{tabular}{|c|c|c|c|c|c|}
\hline Variables & $\begin{array}{c}\text { Very Low } \\
1\end{array}$ & $\begin{array}{c}\text { Low } \\
2 \\
\end{array}$ & $\begin{array}{c}\text { Moderate } \\
3\end{array}$ & $\begin{array}{c}\text { High } \\
4 \\
\end{array}$ & $\begin{array}{c}\text { Very High } \\
5 \\
\end{array}$ \\
\hline GEOMORPHOLOGY & $\begin{array}{l}\text { Rocky } \\
\text { cliffed } \\
\text { coasts, } \\
\text { Fjords }\end{array}$ & $\begin{array}{l}\text { Medium cliffs, } \\
\text { Indented } \\
\text { coasts }\end{array}$ & $\begin{array}{l}\text { Low cliffs, } \\
\text { Glacial drift, } \\
\text { Alluvial plains }\end{array}$ & $\begin{array}{l}\text { Cobble Beaches, } \\
\text { Estuary, Lagoon }\end{array}$ & $\begin{array}{c}\text { Barrier beaches, Sand beaches, } \\
\text { Salt marsh, Mud flats, Deltas, } \\
\text { Mangrove, Coral reefs }\end{array}$ \\
\hline $\begin{array}{l}\text { SHORELINE EROSION/ } \\
\text { ACCRETION (m/yr) }\end{array}$ & $>2.0$ & $1.0-2.0$ & $-1.0-1.0$ & $-2.0--1.0$ & $<-2.0$ \\
\hline COASTAL SLOPE (\%) & $>14.70$ & $10.90-14.69$ & $7.75-10.89$ & $4.60-7.74$ & $<4.59$ \\
\hline $\begin{array}{l}\text { RELATIVE SEA-LEVEL } \\
\text { CHANGE (mm/yr) }\end{array}$ & $<1.8$ & $1.8-2.5$ & $2.5-3.0$ & $3.0-3.4$ & $>3.4$ \\
\hline MEAN WAVE HEIGHT (m) & $<1.1$ & $1.1-2.0$ & $2.01-2.25$ & $2.26-2.6$ & $>2.6$ \\
\hline MEAN TIDE RANGE (m) & $>6.0$ & $4.0-6.0$ & $2.0-4.0$ & $1.0-2.0$ & $<1.0$ \\
\hline
\end{tabular}




\begin{tabular}{|c|c|c|}
\hline Variables & Source & $\begin{array}{c}\text { URL } \\
\text { (Not all sources are downloadable) }\end{array}$ \\
\hline GEOMORPHOLOGY & $\begin{array}{l}\text { Habitat maps produced by } \\
\text { NOAA's Biogeography } \\
\text { Program and 2002-2003 } \\
\text { IKONOS imagery }\end{array}$ & http://www.csc.noaa.gov/islandsgis/resources.html \\
\hline $\begin{array}{c}\text { SHORELINE } \\
\text { EROSION/ACCRETION }(\mathrm{m} / \mathrm{yr})\end{array}$ & $\begin{array}{l}\text { Shoreline change data were } \\
\text { digitized in house for the } \\
\text { 1966-shoreline using US Coast } \\
\text { and Geodetic Survey charts. } \\
\text { The 2002/2003 shoreline was } \\
\text { derived from NOAA's } \\
\text { Biogeography Program } \\
\text { shoreline file for Guam. }\end{array}$ & $\begin{array}{l}\text { http://historicals.ncd.noaa.gov/historicals/histmap.asp } \\
\text { http://biogeo.nos.noaa.gov/projects/mapping/pacific/territories/data/ }\end{array}$ \\
\hline COASTAL SLOPE (\%) & $\begin{array}{l}\text { 1) NGDC ETOPO2 Global 2' } \\
\text { Elevations } \\
\text { 2) Digital Elevation models } \\
\text { produced by NOAA's } \\
\text { Biogeography Program } \\
\text { 3) U.S. Army Engineer Joint } \\
\text { Airborne Lidar Bathymetry } \\
\text { Technical Center of Expertise } \\
\text { (JALBCTX) }\end{array}$ & $\begin{array}{l}\text { http://www.ngdc.noaa.gov/mgg/fliers/01mgg04.html } \\
\text { http://biogeo.nos.noaa.gov/projects/mapping/pacific/territories/data/ } \\
\text { http://shoals.sam.usace.army.mil// }\end{array}$ \\
\hline $\begin{array}{l}\text { RELATIVE SEA-LEVEL CHANGE } \\
\text { (mm/yr) }\end{array}$ & $\begin{array}{l}\text { NOAA Technical Report NOS } \\
\text { CO-OPS } 36 \text { SEA LEVEL } \\
\text { VARIATIONS OF THE UNITED } \\
\text { STATES 1854-1999 } \\
\text { (Zervas, 2001) }\end{array}$ & http://www.co-ops.nos.noaa.gov/publications/techrpt36doc.pdf \\
\hline MEAN WAVE HEIGHT (m) & National Data Buoy Center & http://www.ndbc.noaa.gov/station history.php? station=52009 \\
\hline MEAN TIDE RANGE (m) & $\begin{array}{c}\text { NOAA/NOS CO-OPS Historical } \\
\text { Water Level Station Index }\end{array}$ & http://www.co-ops.nos.noaa.gov/usmap.html \\
\hline
\end{tabular}

